\title{
A STRATEGIC DOCUMENT ON MONETARY POLICY FOR THE PERIOD OF THE INFLATION TARGETING ADOPTION IN UKRAINE
}

\section{Volodymyr Lepushynskyi}

National Bank of Ukraine

\begin{abstract}
The article explains why the Main Guidelines of Monetary Policy need to be adopted in a new format: A monetary policy strategy for 2016-2020. This document must combine the program component (goals, objectives and ways of achieving them) and communication component (explanations in understandable format). Based on international experience of inflation targeting central banks in devising strategic documents on monetary policy, the article offers a format of this document for Ukraine and the key provisions it should include. In particular, it explains the approaches to setting the document's goals, use of the instruments necessary to achieve these goals, decision making procedures, declarations and application of an exchange rate regime, and also communication of monetary decision-making.
\end{abstract}

JEL Code: E520

Keywords: monetary policy strategy, inflation targeting, floating exchange rate

\section{Introduction}

Almost a decade and a half ago, the National Bank of Ukraine has first announced the intention to adopt an inflation targeting regime (NBU Council, 2001). After that, a statement of this intention was repeated in the National Bank's numerous program documents. It continued to be mentioned but was no longer exciting any hopes in economists who take interest in monetary policy.

Let's make it clear from the outset: successfulness of an economy and stability of its monetary unit are determined not by a monetary regime but the country's ability to compete in the global economy. And that requires, first of all, structural reforms.

Ukraine hardly has anything to brag about in this respect. Under these conditions, no modern monetary regime could help regular crises, which befell the Ukrainian economy. Consequently, Ukraine's monetary policy was aimed at offsetting the consequences of these crises. Setting invariable inflation targets and commitments to achieve these targets was, therefore, doomed to fail.

Today, situation is completely different. Implementation of reforms in Ukraine is the matter of national survival. The slogan "Ukraine is doomed to reforms" has become widely popular. It gives chance to a successful implementation of the necessary changes in monetary policy, in particular, evolution of monetary regime in Ukraine into inflation targeting framework. 
Ukraine took the obligation to continue efforts towards future adoption of inflation targeting under Extended Fund Facility program with IMF. This year National Bank of Ukraine made a substantial progress in building policy making procedures, development of analytical and forecasting potential and redesigning monetary policy implementation framework. Now these elements are quite close to inflation targeting central banks.

However, there are still other important elements left: announcement of clear numerical targets for inflation and the National Bank's institutional commitment to achieve these targets. These objectives may be attained by the NBU Board's adoption of a strategic document on monetary policy, the Main Guidelines of Monetary Policy for 2016-2020.

The article offers analysis of other inflation targeting central banks' experience in developing strategic documents on monetary policy and provides recommendations based on this analysis as regards the relevant elements for a similar strategic document for the National Bank of Ukraine.

\section{Strategic documents on monetary policy}

\subsection{International experience}

Most central banks in developing countries which successfully use inflation targeting regime outlined the process of transition to a new regime in a special document: medium-term monetary policy strategy.

Depending on country, these documents have unique features in terms of the scope, content and period for which they were adopted. The documents have different degree of specification: from outlining general goals of monetary policy (Monetary Strategy document of the Czech National Bank) to detailed description of operational objectives (General framework of inflation targeting regime and monetary and exchange rate policy of the Central Bank of Turkey, 2006). Strategic documents on monetary policy approved by central banks of Albania, Georgia, Poland, Serbia have their own particularities as well.

Nevertheless, strategic documents on monetary policy from various countries have common features. First of all, they are program and communication documents simultaneously, because they set out:

- clear and, most importantly, invariable numerical inflation targets. It means not an inflation forecast but target, thus envisaging that monetary policy would be actively aimed at reaching this target;

- target setting procedure and possible reasons for divergence from targets;

- terms and conditions of transition to inflation targeting;

- ways of achieving the central bank's objectives, in particular, determining the main instrument of monetary policy and operations for supporting this instrument;

- motivation to implement inflation targeting, i.e. explanation of why this particular regime is acceptable for the country at a particular stage of its development. Also (which is the most important point in communication aspect), how the implementation of this regime would benefit the ordinary citizen;

- central bank's accountability mechanism, i.e. how the public could learn about the monetary policy measures and success in achieving its goals.

The main reason for publication of this document that is the promulgation and fulfillment of the central bank's commitments is to gain the public credibility, which is critically important for stabilization of inflation expectations.

\subsection{State of affairs in Ukraine}

According to the Law of Ukraine On the National Bank of Ukraine, the Main Guidelines of Monetary Policy (hereinafter referred to as the Main Guidelines) set out the National Bank's performance indicators for the medium-term perspective for the purpose of achieving the National Bank's goals. In other words, there are no de-jure obstacles to turning this document into a monetary policy strategy. 
However, the Main Guidelines for past periods have been significantly different from the aforementioned strategic documents on monetary policy of other central banks. Among the key differences were:

- absence of invariable medium-term goals, principles and objectives of monetary policy. As a rule, the Main Guidelines included a section setting out medium-term goals and objectives. Nevertheless, every year the NBU Board usually approved a revised version of the Main Guidelines for the following year with, most importantly, changed goals. In other words, the central bank had no vision of monetary policy for the medium-term perspective;

- the Main Guidelines were not a clearly program document. It was simultaneously an analytical (an overview of monetary policy within the context of macroeconomic conditions in past years), forecast (a macroeconomic forecast for the following years) and program (setting goals for the following year and, more vaguely, for a medium-term period) document. In fact, this document was, to a large extent, a reiteration of other documents, particularly the NBU Council's evaluation of the monetary policy implementation results, and its forecast section mirrored the Government's relevant forecast. As a result of its multi-functionality, the document's program and especially communicative functions were diluted, because it focused on either the lore of ages long gone by' or second-string information;

- absence of differentiation between targets and forecasts. Before this year's amendment, the Law of Ukraine On the National Bank of Ukraine contained a provision stipulating that the Main Guidelines shall be developed on the basis of indicators calculated by the Cabinet of Ministers. As a result, the Main Guidelines set out a forecast the achievement of which the NBU had to facilitate. If the forecast was changed, the Main Guidelines were amended accordingly as well. However, general practice of central banks shows that the forecast and target of monetary policy have very different functions. The target is a constant, and the policy is aimed at achieving it. If forecasted inflation differs from the target level, a central bank must take the required monetary policy actions.

Moreover, forecast is not a central bank's obligation, and therefore, cannot serve as the anchor for expectations. Harmonization of the Main Guidelines with the best practices of drafting documents of this kind and to the needs of inflation targeting adoption is quite in line with the requirements of law regarding this document's medium-term orientation.

Action required:

- adopting the Main Guidelines as the Monetary Policy Strategy for the Medium-Term Perspective. Timespecific perspective of this document should be harmonized with the period for which Ukraine's other national strategic documents were adopted, first of all, "Ukraine-2020" Sustained Development Strategy approved by a Decree of the President of Ukraine. Considering the foregoing, the revised and updated Main Guidelines should also be adopted for the period of 2016-2020;

- the Main Guidelines should become a program and communication document, which means that its content must be compact. The Main Guidelines' section pertaining to evaluation of the monetary policy implementation results must become a separate document to be approved by the NBU Board, whereas macroeconomic forecasts are already being published in a separate document: NBU Inflation Report (where the NBU should analyze how forecasts are correlated with declared targets);

- setting numerical targets, emphasizing their invariability and aiming monetary policy at achieving them. If the target could not be achieved in a short-term run, this should not be a reason for revising it; on the contrary, the NBU has to clearly explain how the changes in its instruments would bring actual inflation indicators back to the target level. Clarity of commitments and transparency of fulfillment actions must become the pillars of the NBU credibility.

The above actions are quite real to realize, especially considering the legislative amendments concerning development of the National Bank of Ukraine's institutional capability. Detailed overview of the monetary policy's aspects which we propose to highlight in the revised Main Guidelines is provided below. 


\section{Motivating the implementation of inflation targeting regime}

As international experience proves, the presence of "Motivation" section is an important feature of medium-term monetary policy documents. This section describes the desired state a central bank intends to achieve and the benefits it would bring to the economy in general and for every ordinary citizen in particular. This section also outlines the reasons why a central bank has chosen particularly the inflation targeting rather than other alternative regimes to achieve the desired state.

It's not a secret that for decades, Ukrainian economy has been suffering from volatile and unpredictable inflation that undermined the hryvnia's credibility. While in the early 1990s, high inflation was an inevitable consequence of transformational processes, afterwards it became the result of an unreasoned macroeconomic policy, which had a substantial populist component. Thus, during some periods, inflation was declining to low levels and even deflation became. But what's important is that inflation fluctuated significantly during quite short periods of time. In view of the above, high inflation expectations persisted in the society, finding their reflection in:

- high interest rates on hryvnia deposits and, therefore, hryvnia loans;

- inclination toward dollarization of both savings (foreign currency is one of the means of protecting them against depreciation) and loans (because the costs of foreign-currency resources are lower);

- volatile conditions of running a business and deteriorating business environment.

Therefore, having reached the desired target of low and stable inflation, the NBU can ensure that:

- inflation would no longer be a significant reason to worry about for households and businesses;

- credibility of the hryvnia would grow, helping expand the sphere of its use and driving dedollarization;

- individual savings and income would be protected against depreciation;

- low nominal interest rates would stimulate investments and economic growth;

- private individuals and businesses would adequately assess foreign exchange risks and would be ready to potentially substantial fluctuations of the exchange rate.

Why only the inflation targeting regime could help achieve this environment? And why a chance for successful implementation of inflation targeting is in the nearest future, if it wasn't done in the past almost 15 years? The answer is quite simple: Ukraine simply has no other alternative.

There are three main monetary regime types in the world: exchange rate pegging, monetary targeting (monetary aggregates targeting) and inflation targeting. There are regimes that do not fall under this classification, but mostly, they are either eclectic (setting many targets which, as a rule, a central bank cannot successfully achieve) or transitional between the aforementioned regimes.

One of the key advantages of inflation targeting is that it envisages clear framework of transparent policymaking aimed at price stability in medium term perspective while allowing some degree of freedom to react on external and domestic shocks in short run. Results of empirical studies demonstrated that (Roger, 2010; Jahan, 2012):

- inflation expectations are under more efficient control and more stable in countries which are practicing inflation targeting;

- countries that adopted inflation targeting especially emerging market economies have made substantial progress in disinflation for last 20 years and are more protected from external shocks and crisis (GDP loss and inflation acceleration are smaller).

Regimes alternative to inflation targeting have substantial drawbacks that make them unsuitable for Ukraine. 
The exchange rate pegging regime is not suitable for Ukraine for many reasons. The most obvious one is that in order to maintain the national currency pegged to, say, the US dollar, the NBU has to have large international reserves. But unfortunately, this precondition is nonexistent in our country. Otherwise, this regime is doomed to fail.

One should also not forget that the exchange rate pegging regime led to accumulation of substantial macroeconomic imbalances in the past. It didn't create conditions for but led to them. The reckless macroeconomic policy resulted in the country living "beyond its means", which was vividly reflected in the critical figures of BoP current account deficit (9\% of GDP in 2013). The exchange rate pegging helped defer for some time the hryvnia's inevitable devaluation, but only by "eating away" the nation's international reserves and postponing the inevitable correction of exchange rate.

In addition, longstanding exchange rate pegging created wrong impression of businesses and households regarding foreign exchange risks. Under this impression, they incautiously assumed foreign-currency liabilities. The consequences of those actions continue to cause social tensions till present day, despite the de-facto prohibition on providing individual financing in foreign currency lasting for many years.

Therefore, maintenance of the exchange rate pegging regime creates risks for Ukraine to go through all the consequences of past crises it went through before.

Ukrainian economy is small and open, which means that it doesn't set the rules of the game on the global scale but only follows them. For an economy like that, flexible exchange rate must play the role of "buffer" against outside shocks. What does that mean for the ordinary citizen and why would he need these exchange rate fluctuations which only cause him headache?

The answer is simple: sustaining of the employment, because if the demand or prices for Ukrainian goods on foreign markets decline, the hryvnia must depreciate to keep the prices for Ukrainian goods competitive and help businesses retain their sales markets and, consequently, their employees keep the job.

To be sure, adverse consequences such as declining capacity of the ordinary citizen to buy imported goods or to travel abroad are present, but these consequences are much "softer" comparing to the growing unemployment on the nationwide scale.

The reverse situation is also possible: as a result of a positive external shock when the growing foreign demand or export prices threaten "overheating" of the economy, a stronger hryvnia becomes a "safety device" preventing accelerating inflation.

Overall, in the countries with floating exchange rate the volatility of this indicator is higher (Klein and Shambaugh, 2009). Nevertheless, nominal volatility of exchange rate helps stabilize real economic growth. That's what they mean by saying that exchange rate serves as a buffer against external shocks (see: Section 2). According to the study by Edwards and Yeyati, in countries employing tighter monetary regimes, trade condition shocks are amplified. All other conditions equal, economies with flexible exchange rates are growing at a higher rate comparing to countries with a fixed exchange rate (Edwards and Yeyati, 2004).

Edwards notes that fluctuations of a floating exchange rate are diminishing if inflation targeting is also used. The reason for that is that "inflation targeting is a transparent and predictable monetary regime serving to absorb unforeseen shocks or "news" (Edwards, 2006).

Does floating exchange rate mean that it is going to lower without alternative? Definitely not. All depends on the success of structural reforms which would determine the economy's competitiveness and on the external environment. Exchange rate fluctuations would only protect the national economy against sharp changes in global market conditions. For example, recalling Poland's experience, the exchange rate of the Polish zloty to euro is presently at approximately the same level as when inflation targeting was introduced there almost 15 years ago, although during this period, the exchange rate's fluctuations were, at times, over $30 \%$.

There is an erroneous opinion that the central bank using this regime cannot intervene in the foreign exchange market. However, according to the IMF's definition, the use of this regime involves "interventions (direct or indirect) on the foreign exchange market aimed at moderating the rate of change and preventing undue fluctuations in the exchange rate" (IMF, 2014). The main 
criterion of this regime is that official intervention policy should not be aimed at establishing a certain level (or band) for the exchange rate.

In other words, the National Bank may smooth exchange rate fluctuations but should not intervene to counter a currency appreciation or depreciation trend.

Using a floating exchange rate also complies with one of the National Bank's most important objectives for the next several years: restoration of international reserves. Considering the unstable economic situation and volatile market expectations, an adequate level of international reserves would ensure stability of financial system and protect the economy from potential shocks.

The National Bank must replenish its international reserves without hampering the efforts of achieving price stability while at the same time maintaining a floating exchange rate. The objectives of interventions on the foreign exchange market and inflation targets may conflict with each other. For example, in an attempt to accumulate reserves a central bank may lower the exchange rate, thus sacrificing price stability. Therefore, priorities must be set to prevent the conflict of objectives; in particular, price stability must have the unquestionable priority when implementing monetary policy.

At the same time, accumulation of international reserves should not result in fixing the exchange rate. To avoid it, a prudent intervention strategy should be devised: the National Bank should not counter sustained hryvnia appreciation or depreciation trends caused by fundamental factors.

The potential for the exchange rate to fluctuate toward either appreciation or depreciation serves as an important factor preventing business entities from taking excessive foreign exchange risks.

However, it worth mentioning even when the switch to floating exchange rate has come into effect, public attention would focus, to a large degree, on the exchange rate which would still remain for a while a de-facto "anchor" for expectations. Only afterwards, when a central bank was able to bring inflation to a low and stable level public attention would shift from the exchange rate to inflation rate. Considering such a significance of the exchange rate, strategic documents on monetary policy devote a separate section to the coverage of abovementioned goals of the central bank's currency exchange policy. The National Bank's strategic document should have this section as well.

Another type of monetary regime is monetary targeting. This is a regime which is currently used de-jure in Ukraine. The stand-by agreement with the International Monetary Fund (IMF) sets the quantitative criterion of efficiency for the net domestic asset growth and an indicative target for monetary base.

This is the IMF's standard practice of setting "safeguards" preventing central banks from conducting a too expansive policy incompatible with the programs`stabilization objectives.

However, efficient application of monetary targeting to control inflationary processes requires close correlation between money supply and prices. The absence of this correlation in the short- and medium-term perspective led to the abolition of monetary targeting in all developed countries which employed it and the majority of developing countries where this correlation is much weaker (IMF, 2014a).

It is worth noting that for countries de-facto using or switching to inflation targeting regime, the money supply growth criteria set out in IMF programs may not apply; instead, the Monetary Policy Consultation Clause applies. What it actually offers is a quarterly or half-year evaluation of inflation deviations from target levels by IMF experts in the form of formal consultations with authorities to bring the relevant indicators into accordance with target trajectory. Ukraine can also count on the switch to this format of cooperation with the IMF, if it could prove its determination to implement inflation targeting. The IMF says that the Monetary Policy Consultation Clause could be implemented either with the launch of a new program or in the event of modification of existing IMF programs (IMF, 2014a).

The absence of the commitment to follow preset target values of monetary indicators gives monetary policy a greater flexibility. It allows a central bank to focus on inflation targets. Nevertheless, quantitative monetary indicators remain an important component of the central bank's analysis which supplements conventional economic analysis. In particular, loan and monetary aggregate data contain important information regarding pricing and financial stability risks (Bernard et all, 2015). 


\section{Stages of transition to inflation targeting in Ukraine}

Can the National Bank switch to inflation targeting in the nearest future, say, in 2016? To begin with, we have to define for ourselves what inflation targeting is. During more than decade of discussions about the necessary preconditions for implementation of inflation targeting in Ukraine, they have already turned into a mantra. One could even get an impression that for this transition to take place, Ukrainian economy first has to catch up with the UK or Canada.

Definition of inflation targeting in the IMF's De Facto Classification of Exchange Rate Regimes and Monetary Policy Frameworks is worth recalling: "This [regime] involves the public announcement of medium-term numerical targets for inflation with an institutional commitment by the monetary authority to achieve these targets. Additional key features include increased communication with the public and the markets about the plans and objectives of monetary policymakers and increased accountability of the central bank for attaining its inflation objectives. Monetary policy decisions are guided by the deviation of forecasts of future inflation from the announced target, with the inflation forecast acting (implicitly or explicitly) as the intermediate target of monetary policy" (IMF, 2008).

In other words, it mentions, first of all, the central bank's operational procedures: announcement of a target, commitment to this target, substantiation and communication of monetary policymaking decisions.

In fact, the majority of developing countries began transition to inflation targeting during a crisis or post-crisis period when other monetary regimes were impossible to apply. These periods saw the absence of both macroeconomic stability and a sophisticated financial system usually mentioned as preconditions for an effective application of this regime (Schaechter and Zelmer, 2000). At the same time, it did not interfere the overwhelming majority of these countries with subsequently stabilizing inflation at a low level. The example of the Czech Republic, which switched to inflation targeting in a crisis period when exchange rate pegging was impossible to maintain is worth recalling.

Transition to an inflation targeting regime may begin before all required preconditions are in place, if there is a clear commitment to achieve a complete implementation of this regime (IMF, 2014b). Moreover, as international experience proves, the transition to inflation targeting per se often becomes a catalyst of institutional changes in the country, particularly improvement of fiscal discipline or development of financial markets (Batini et al., 2005).

A similar situation is currently observed in Ukraine: given the absence of effective alternatives to inflation targeting, there are actually no obstacles to organizing of the National Bank's procedures in accordance with the inflation targeting regime's standards. Many of them have already been de-facto implemented, first of all:

- a decision-making system based on macroeconomic forecasts: regular monthly meetings of the Monetary Policy Committee presently transformed into regular meetings of the National Bank's Board on monetary issues (after amendment of the Law of Ukraine On the National Bank of Ukraine);

- analytical potential of supporting medium-term monetary policymaking decisions, first of all, inflation forecasting tools (Nikolaychuk and Sholomytskyi, in print);

- operating approaches to implementation of monetary policy, in particular, increasing the effect of interest rates on the National Bank's operations on short-term interest rates on interbank financing market;

- the National Bank's communications with the market, increasing accountability for its monetary policymaking decisions.

However, there are still other important elements left: announcement of clear numerical targets for inflation and the National Bank's institutional commitment to achieve these targets. These objectives may be attained by the NBU Board's adoption of a strategic document on monetary policy, the Main Guidelines of Monetary Policy for 2016-2020.

In that case, evolution of monetary regime in Ukraine may take the following form (Figure 1): 
Figure 1. Possible evolution of monetary regime in Ukraine

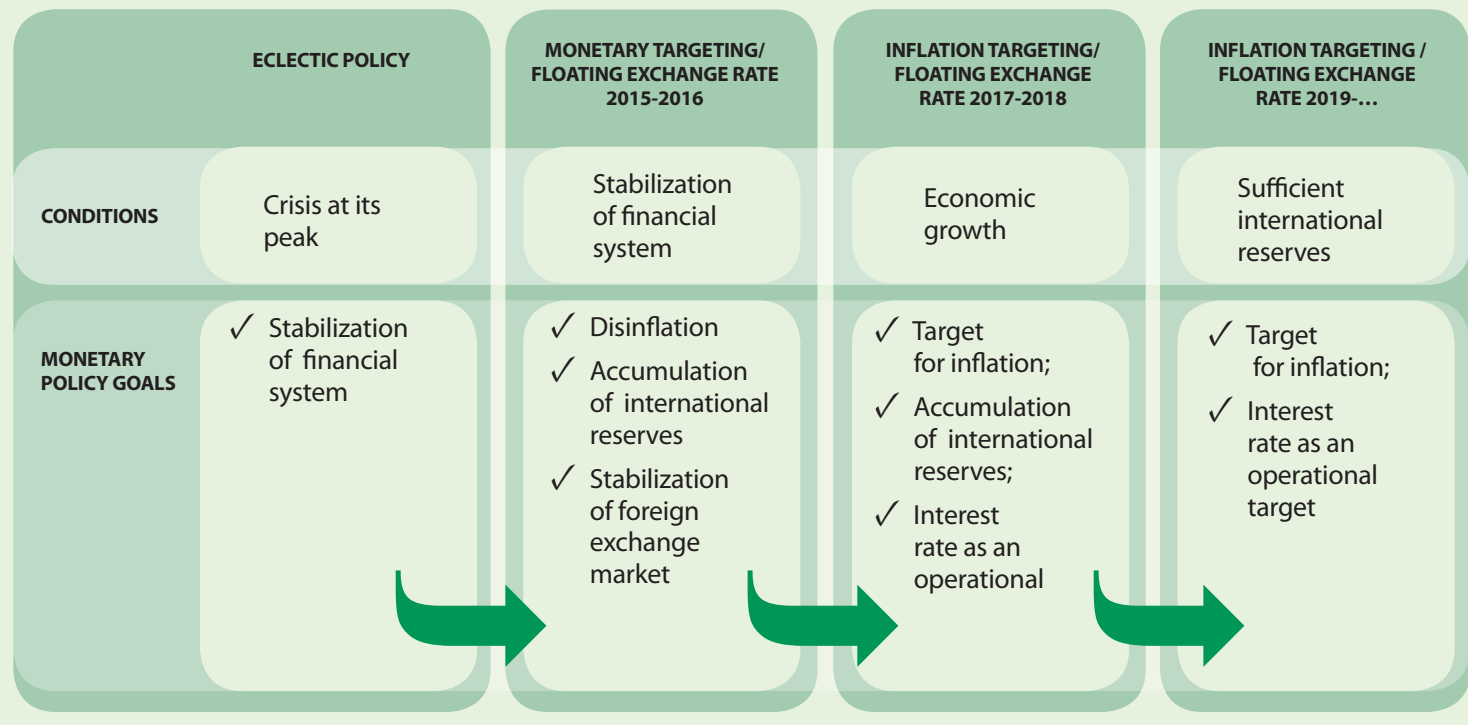

1. Eclectic monetary policy: a past stage. During a macroeconomic, banking and currency crisis, monetary policy was aimed at attaining a wide range of objectives associated with maintaining the country's viability and avoiding collapse of financial system.

2. Breakaway from eclecticity in monetary policy, which became possible after adverse effects of crisis were mitigated and banking system was "cleaned up". Monetary targeting is the current stage. According to its obligations under the IMF's Stand-By Program, the National Bank has to attain numerical targets for money supply. That is a de-jure monetary policy regime, although as mentioned earlier, a large number of the National Bank's procedures are presently conformable to a "lite" inflation targeting regime, i.e. without announcing short-term numerical targets for inflation.

3. Inflation targeting. Switching to this regime requires announcement of numerical targets for inflation and appropriate modification of IMF's Stand-By Program criteria. This regime should be announced when actual inflation rate in Ukraine declines to a moderate level (say, around 10\%). What makes this regime different from the "classical" inflation targeting is the existence of a target for international reserves accumulation.

4. "Classic" inflation targeting. Switching to this regime would, to a certain degree, be symbolic, because it won't require announcements or procedure changes. Inflation has to reach a medium-term target level, and monetary policy must be aimed at attaining this objective. By that time, international reserves should grow to a sufficient level, which means that reserve accumulation target would no longer be on agenda.

\section{Inflation targets}

The announcement of clear (numerical) targets for inflation and the mechanism of achieving them must be one of the key elements of a strategic document on monetary policy.

\subsection{Setting targets}

When devising a strategic document, a number of questions which usually cause broad discussion have to be answered:

\section{Who is responsible for setting inflation targets?}

In the case of Ukraine, the answer is obvious: Council of the National Bank. Some countries using inflation targeting regime cannot independently adopt inflation targets (because this is a parliament's, government's, or joint government's and central bank's responsibility). Considering the foregoing, setting a target for inflation requires coordination with the government or other public institutions. In particular, it requires execution of a joint Memorandum between the government and central bank on joint recognition of inflation targets. In Ukraine, the body responsible for adoption of the Main Guidelines is a separate supervisory body operating within the National Bank's organization. Therefore, setting inflation targets is fully within the National Bank's competence. 


\section{What indicator should be used as an inflation target?}

As of today, all countries employing inflation targeting use the Consumer Price Index (CPI) as the target price indicator, although in the beginning of the new monetary regime's implementation process, some of them (e.g. Czech Republic, South Korea) used core inflation as the target indicator.

The main reasons for using the CPI (and not another price indicator, e.g. GDP deflator that has more solid theoretical base) are operational: calculations are done monthly and with the minimum time lag, no need for statistical revisions of past period data.The key advantages of using the total CPI vs core CPI include:

- easy to perceive and monitor by the public;

- full coverage of the consumer basket without excluding some of its components (which could be extremely important for particular consumer groups);

- comparability with other countries.

The key drawback of the total CPI lies in its high volatility caused by the effect of non-monetary factors, which complicates the achievement of inflation targets. Nevertheless, this drawback can be largely offset if the central bank provides a clear explanation of possible reasons hampering achieving of desired targets.

\section{What kind of target should it be: a point or a band?}

An inflation target may be set as a point or a band, the so-called "comfort zone". Comfort zones are seldom used by central banks to set inflation targets. In particular, the former member of the Board of Governors of the Federal Reserve System Frederic Mishkin criticized, in his speech ironically titled Comfort Zones, Shmumfort Zones, the practice of setting inflation targets in this form. He concludes that it makes interpretation of a target difficult. For example, if a target band is set at 1-2\%, it means that a central bank is equally tolerant toward inflation which has the rate of $1.1 \%$ or $1.9 \%$. It complicates both formulation of monetary policy (due to the absence of a clear target which should be oriented at when making decisions) and communications with the public (Mishkin, 2008).

Considering the foregoing, setting comfort zones for inflation targets is considered inadvisable for anchoring expectations, because the central bank does not publish a single figure to which expectations could be "tied". The aforementioned drawbacks would amplify if we take into account that for developing economies the comfort zone must be wider than 1-2\%.

Considering all these drawbacks, setting targets as points (with an interval of possible divergences) is the most popular approach today for countries with inflation targeting: it is used in 17 out of 27 countries. Another five countries use point targets only (Hammond, 2012), because a clearly set numerical target brings maximum advantage to effective communications with the public and to management of inflation expectations.

The point-based approach to setting a medium-term target for inflation is recommended for the National Bank of Ukraine. Point targets with an interval of possible divergences are proposed to determine and achieve disinflation trajectory. Setting target as a point would anchor inflation expectations of the public, which is one of the important elements of macroeconomic stability. At the same time, an interval of possible divergences for targets set for specific years would give the National Bank certain flexibility in managing inflation which could become volatile due to short-term and insignificant shocks that do not require response from monetary policy.

What level of inflation should be associated with price stability in the medium-term perspective? What should disinflation trend look like in order to achieve it?

Medium-term targets for inflation in developing countries are usually several percentage points higher than inflation targets in developed countries (Hammond, 2012). It can be explained by:

1. Higher degree of uncertainty / shocks caused by structural adjustments;

2. Greater errors in inflation measurements;

3. Substantial changes in relative prices due to higher labor productivity growth rates in the tradable sector (the Balassa-Samuelson effect). 
The following estimates of optimal inflation rates in the medium-term perspective are available for Ukraine:

- Petryk and Nikolaychuk (2007): 4\% (based on an analysis of changes in relative prices and keeping inflation of tradable goods at the level of developed countries);

- $\operatorname{IMF}(2014): 3 \%-5 \%$;

- Gorodnichenko (2014): 3\% - 5\% (by extrapolating an optimal inflation model for the U.S. based on maximizing the usefulness function in the condition of zero lower limit of interest rates, taking into account the greater (2-3 times) magnitude of macroeconomic shocks in Ukraine).

The Main Guidelines of Monetary Policy for 2015 have already set the medium-term target for the CPI growth rate at $5 \% \pm$ $1 \mathrm{pp}$. This target was set on the basis of the aforementioned studies and must be enchrined in a strategic document on monetary policy. At the same time, it should be communicated as a point target without a divergence interval, defining the level which the National Bank intends to achieve in the medium-term perspective.

At the same time, specific targets for the coming years that outline a gradual disinflation process required to attain a medium-term target for inflation should be set as a point with a gradually-narrowing interval. A wide interval is necessary at the initial stages, in particular, to increase flexibility of monetary policy when responding to short-term shocks whose impact could be substantial in the initial phases of post-crisis recovery.

Considering the macroeconomic forecast for the coming years, expected growth of administratively-regulated prices and tariffs, and the need to better stimulate the economy for post-crisis recovery, the downward dynamics of inflation targets (in terms of the total CPI growth rate) in the coming years must be low-inclined (Figure 2):

- December 2016: $12 \pm 3 \%$ year-on-year;

- December 2017: $8 \pm 2 \%$ year-on-year;

- December 2018: $6 \pm 2 \%$ year-on-year;

- December 2019 and beyond: $5 \pm 1 \%$ year-on-year.

Figure 2. Possible trajectory of medium-term targets for inflation in Ukraine

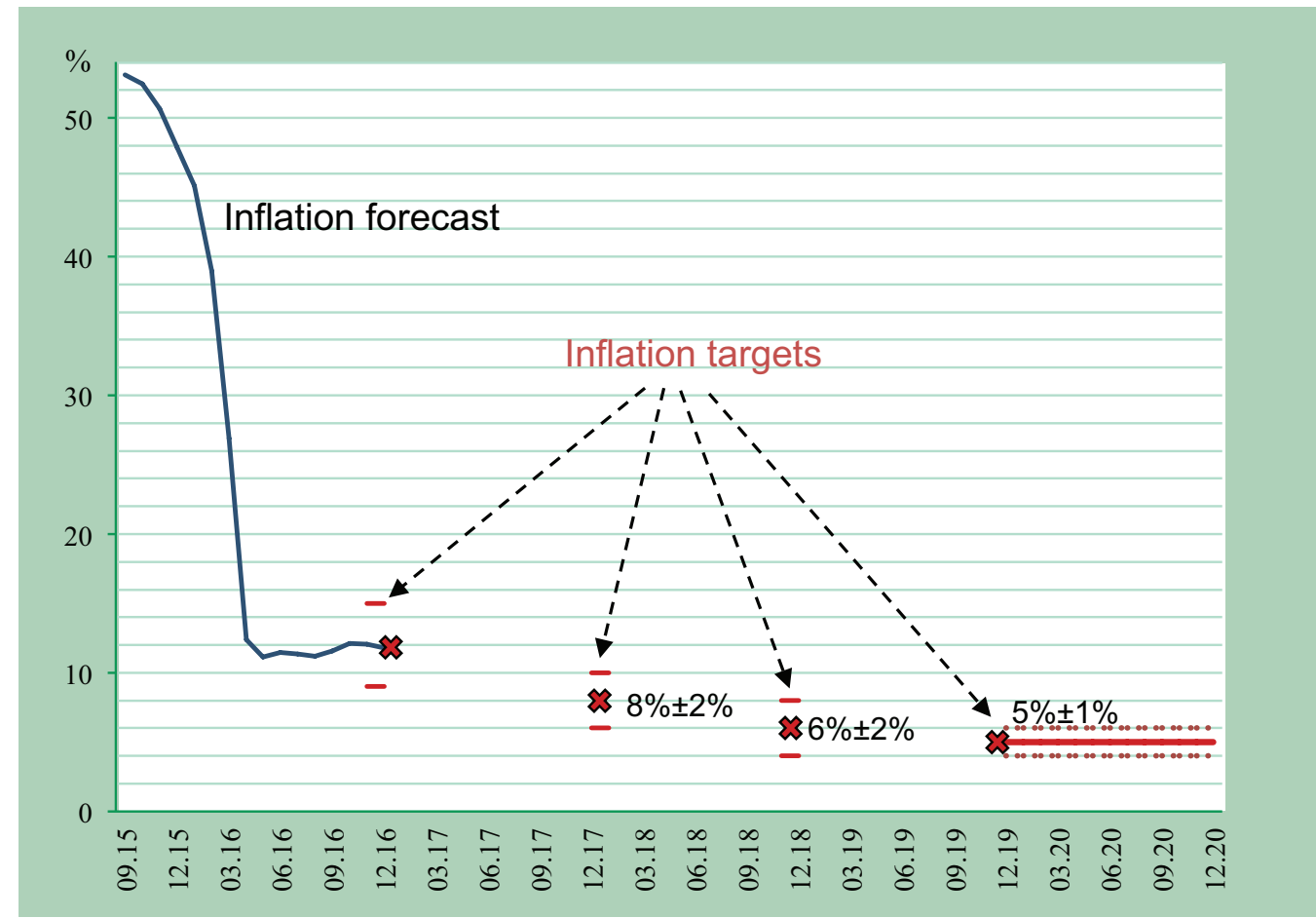




\section{Possible reasons preventing attainment of inflation targets}

Since the strategic document on monetary policy envisages invariability of inflation targets, it should identify the reasons allowing for divergence of actual inflation from inflation targets.

In a short-term period, inflation may diverge from preannounced targets due to impact of external and internal shocks which are beyond monetary policy's control, such as, in particular, changing prices for raw materials and other highly-volatile components of the Consumer Price Index, divergence of administratively-regulated prices from preannounced levels, etc.

Under these circumstances, bringing inflation to a target level in the shortest possible time could be very costly from the viewpoint of economic growth. The aforementioned shocks are inflationary, but they simultaneously cause consumer demand to shrink, which slows down inflation (with a certain lag). Therefore, a tighter monetary policy in response to these shocks would be counterproductive, considering that monetary policymaking decisions must take into account, first of all, inflation forecast.

Therefore, monetary policy must focus on preventing realization of secondary effects from these shocks, i.e. their effect on inflation expectations, thus achieving the medium-term targets for price stability. The period of time during which inflation must be brought into accordance with the medium-term target should be clearly defined in every event like that and communicated to the public.

\subsection{Achieving inflation targets}

The inflation targeting practice envisages a quite clear procedure of making monetary policymaking decisions aimed at achieving inflation targets. Its definition in strategic documents on monetary policy has different scope and specification, but nevertheless, it includes, as a rule:

- monetary policy key interest rate (hereinafter referred to as the key interest rate) as the main instrument of monetary policy;

- pegging the pricing of the main liquidity regulation instrument to the key interest rate - provision or withdrawal thereof depending on the structural position of banking system's liquidity (deficit or surplus). This instrument must have the greatest effect on the interbank credit market interest rates which then would influence interest rates on other banking operations;

- regular procedure of making and communicating decisions on the key interest rate;

- monetary policy secondary instruments supporting the main instrument.

The foregoing is important from the viewpoint of expectations formation on monetary market: by announcing its key interest rate, a central bank sets a benchmark for the market value of monetary resources.

Considering the above, the National Bank's strategic document on monetary policy should include the following in the "achieving inflation targets" section:

- setting out the key interest rate: interest rate on main liquidity regulation instruments, i.e. instruments, which have the greatest influence on the market. This rate must be synchronized with the discount rate which de-jure serves as the benchmark value of money. The National Bank must clearly declare which of its operations are main operations, and set a fixed interest rate for them. In that case, the market's attention will be focused on the change of interest rates on these operations and the response to these changes will be quick. Bearing in mind that banking system presently experiences structural surplus of liquidity, these operations should involve floatation of deposit certificates (for 7 or 14 days). In case of structural liquidity deficit refinancing tenders of the NBU could be treated as the main policy instrument and interest rate on this instrument could be treated as the key rate;

- declaring that decisions on the key interest rate will be based on macroeconomic forecast, first of all in order to bring inflation forecast to a target value. Monetary policymaking decisions also require a comprehensive analysis of macroeconomic, monetary and financial indicators which helps identify price stability risks; 
- regular (according to a preannounced schedule) meetings of the National Bank's Monetary Policy Board with publication of Board decisions made at these meetings;

- setting a bandwidth for overnight rates (on the National Bank's overnight loans and deposit certificates) as a mechanism of supporting the key interest rate. This bandwidth would limit interest rate fluctuations on the interbank market around the key interest rate;

- description of other supporting operations intended, first of all, to increase the main instrument's effectiveness. Unlike the main instrument, these operations would not influence the market value of resources but serve to amplify its effect.

The National Bank is already actively using many of these elements. In particular, change of the National Bank's interest rates already influences the dynamics of interest rates on the interbank market. However, interest rates on the main liquidity regulation operations (which are interest rates on deposit certificates) need to be converged to the discount rate which dejure serves as the benchmark value of money.

\section{Monetary policy communications}

There is a famous saying that money likes silence. But speaking about the central bank's activity, it's worth adding that the silence should not be anguishing. Thus, the central bank is an independent institution. But all business entities are dependent on the central bank, because to a substantial degree, their wellbeing depends on it.

There is a broad consensus among the scholars that besides ensuring the central bank's public accountability, transparency of monetary policy may boost its effectiveness (Blinder, 1998; Woodford, 2003).

That's why the communications section is an essential component of strategic documents on monetary policy.

It is extremely important that the society understands that the central bank's activity is adequate to its priority objective maintaining inflation at a low, stable level. As the former Chief Economist of the European Central Bank O. Issing said: "Openness and clarity are equally important for transparency of monetary policy" (Issing, 1999).

In other words, the openness (you can see what you want, we have nothing to hide) is as important as competently built communications. The society needs to have enough information to assess reasonability of decisions made in monetary sphere.

Under the exchange rate pegging regime, communications do not play such a decisive role, because expectations are influenced only by the invariability of the exchange rate today and tomorrow. On the contrary, under inflation targeting regime, communication attains the exceptional importance, because the public needs to understand how a monetary policymaking decision made today would facilitate, via the chains of macroeconomic variables called transmission mechanism, price stability in the medium-term perspective. For that, it is the only way to stabilize inflation expectations, which is what inflation targeting is needed for at the end of the day.

Many communication elements, typical for inflation targeting regime, have already been implemented at the National Bank of Ukraine. In particular, in March 2015 it published the first Inflation Report which serves as the key instrument in central banks' communications under inflation targeting regime. Quarterly publications of this document help convey to the public, in a simplified (adapted) format, the array of data which the central bank uses to make decisions, in particular: on-the-day macroeconomic forecast with the focus on inflation, price stability risks and, in the end, National Bank's measures taken to offset these risks.

An important element of the central bank's communications under inflation targeting regime is a proper substantiation and communication of its monetary policymaking decisions. In doing so, it is important to build the so-called "routine cycle" of making decisions with regard to key instruments. After all, the central bank is not a news agency and the purpose of its communications is not to broadcast sensations and "canards" but, on the contrary, constant (routine) explanation, in easy-tounderstand form supported by facts, of how its measures would help achieve inflation targets. 
Advantages of building a routine cycle:

- Predictability of central bank's actions, for barring extraordinary events, all decisions are made right according to the schedule. Unlike the practice of making spontaneous decisions, it allows to place an emphasis on the consistent policy aimed at achieving medium-term targets;

- Facilitating equal access to information, because a decision becomes known to all market participants at the same time and the only source of information is the central bank;

- Tying market expectations regarding the change of monetary instruments to a particular regular event (press conference, press release, etc.), thus improving effectiveness of these instruments;

- Increasing transparency and accountability and expanding dialogue with markets. Regular explanations by the central bank of its monetary policymaking decisions help better perceive and understand these decisions by financial market participants.

In order to build this routine cycle, the National Bank has launched monthly meetings of the Monetary Policy Committee (the Committee) held according to a preannounced schedule. After every meeting, the Committee used to publish a press release explaining decisions it made with regard to monetary policy instruments.

Presently, in view of the enactment of legislative changes enhancing the National Bank's institutional capability which reformed, in particular, working principles of the National Bank's Board, the approaches to the adoption and communication of monetary policymaking decisions have somewhat changed as well. The Committee meetings remain an important platform for discussion of monetary policymaking decisions, thus improving their justifiability. At the same time, decisions will now be de-jure and de-facto adopted at the regular meetings of the National Bank's Board for Monetary issues.

To build a full-fledged routine cycle, changes in monetary instruments have to be announced not only on a predetermined day but at the same time. That's the area where the National Bank is currently improving the relevant processes.

In particular, taking into account the operating practice of leading central banks, the National Bank's routine cycle may look as follows (Figure 3):

Phase 1: One week before the National Bank's Board makes a decision. Preparation by the National Bank's departments concerned of a macroeconomic forecast, expanded analysis of economic conditions, monetary indicators and financial stability, and development on this basis of a staff proposal regarding monetary policy for the National Bank's Board.

Phase 2: The day before the National Bank's Board makes a decision. The Committee holds a meeting which plays an important role in getting a full "macroeconomic picture". The meeting is attended by the Bank's staff (directors of Departments for Monetary Policy and Economic Analysis, Open Market Operations, Financial Stability, Statistics and Reporting) and members of the National Bank's Board. At these meetings, the Bank's staff makes presentations of macroeconomic forecast, development of financial markets and financial stability, reports analysis results, shares experience and opinions with the National Bank's Board members who make the decision.

Phase 3: Day when the National Bank's Board makes a decision. Presentation of a staff proposal to the National Bank's Board.

Phase 4: Decision Monetary policy is made by the National Bank's Board.

Phase 5: Communication of a National Bank's Board's decision (at a specifically-determined time on a decision adoption day). 
Figure 3. Possible scheme of organizing a "routine cycle" of adopting and communicating monetary policymaking decisions at the National Bank.

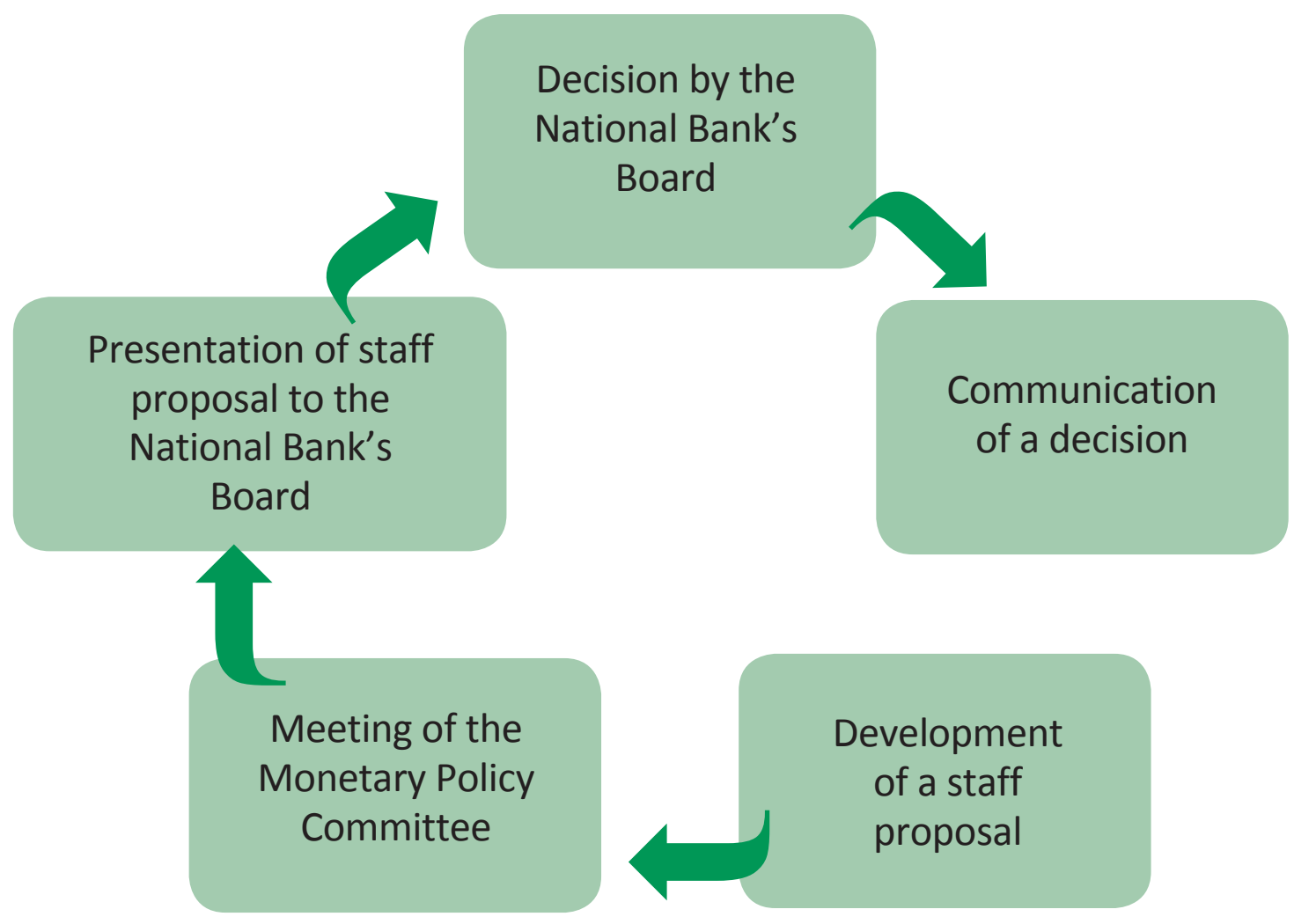

\section{Concluding remarks and recommendations}

Today, the adoption by the National Bank's Council of the Main Guidelines of Monetary Policy in a new format, format of the National Bank's monetary policy strategy for 2016-2020 remains a contemporary objective. This document must have program component (setting monetary policy goals and ways of achieving them) and communication component (conveying goals and objectives to the public in an easy-to-understand form).

Taking into account international experience, this document must include:

1. Explanation of advantages of a chosen monetary strategy;

2. Clear commitment to adopt inflation targeting by the particular deadline;

3. Medium-term price stability target (5\% for CPI year-on-year change) and clear trajectory of achieving it. These targets must be invariable in order to gain public trust;

4. Definition of:

- instruments and procedures for achieving inflation targets;

- goals of foreign exchange policy under floating exchange rate regime;

5. Description of monetary policy goals and decisions communication strategy.

Declaration by the National Bank of clear goals for monetary policy, mechanisms of achieving them and fulfillment of its commitments will help increase public credibility and stabilize inflation expectations, thus setting a necessary precondition for price stability. 


\section{References}

- Bank of Albania (2008). Monetary Policy Document for the 2009-2011 period.

- Batini N., Kuttner K., Laxton D. (2005). Does Inflation Targeting Work in Emerging Markets? Chapter 4 of the September 2005 World Economic Outlook, International Monetary Fund.

- Blinder A. (1998). Central Banking in Theory and Practice, MIT Press, Cambridge MA.

- Central Bank of Turkey (2006). General framework of inflation targeting regime and monetary and exchange rate policy for 2006.

- Council of the National Bank of Ukraine (2001). Main guidelines of monetary policy for year 2001, elaborated and approved by the Council of the National Bank of Ukraine.

- Czech National Bank, CNB Monetary Strategy document. Available at:

https://www.cnb.cz/en/monetary_policy/strategic_documents/c_dms.html

- Edwards S. (2006). The relationship between exchange rates and inflation targeting revisted. Working paper, No. 12163, NBER.

- Edwards S., Yeyati L. (2004). Flexible exchange rates as shock absorbers. European Economic Review, No. 49, pp. $2079-2105$.

- Gorodnichenko Y. (2014). Inflation target for Ukraine, VoxUkraine Blog. Available at: http://voxukraine.blogspot.com/2014/05/IT.html

- Hammond G. (2012). State of the art of inflation targeting - 2012, Bank of England, CCBS Handbook, No. 29.

- IMF (2014 a). Conditionality in Evolving Monetary Policy Regimes, IMF Policy Papers.

- IMF (2014 b). First IMF Central Bank Forum for Developing Markets: The Road to Inflation Targeting and Transitional Monetary Arrangements, Press Release, No. 14-435.

- IMF (2014 c). Annual Report on Exchange Arrangements and Exchange Restrictions 2014.

- IMF (2014 d). De Facto Classification of Exchange Rate Regimes and Monetary Policy Frameworks.

- IMF (2014 e). Ukraine: Request for a Stand-By Arrangement-Staff Report; Supplement; Staff Statement; Press Release; and Statement by the Executive Director for Ukraine. Country Report, No. 14/106, IMF. Available at: http://www.imf.org/external/pubs/ft/scr/2014/cr14106.pdf

- Issing O. (1999). The Eurosystem: Transparent and Accountable, or Willem in Euroland. Journal of Common Market Studies, Vol. 37, No. 3, pp. 503-519. https://doi.org/10.1111/1468-5965.00175

- Jahan S. (2012). Inflation Targeting: Holding the Line. Finance \& Development, IMF, Washington, DC.

- Klein M.W, Shambaugh J.C. (2009). Exchange Rate Regimes in the Modern Era, The MIT Press.

- Laurens B., Eckhold K., King D., Maehle N., Naseer A., Durré A. (2015). The Journey to Inflation Targeting: Easier Said than Done. The Case for Transitional Arrangements along the Road. Working Paper, No. 15-136, IMF.

- Mishkin F.S. (2008). Comfort Zones, Shmumfort Zones: A Speech at the Sandridge Lecture of the Virginia Association of Economists and the H. Parker Willis Lecture of Washington and Lee University, Lexington, Virginia.

- National Bank of Georgia. Monetary Policy Strategy of the National Bank of Georgia. Available at:

https://www.nbg.gov.ge/index.php?m=628\&lng=eng

- National Bank of Poland (1998). Medium-Term Strategy of Monetary Policy (1999-2003).

- National Bank of Serbia (2006). Memorandum National Bank of Serbia on the Principles of the New Monetary Policy Framework Aiming at Low Inflation Objectives. Available at:

https://www.nbs.rs/internet/english/30/Memorandum_new_monetary_policy_framework_200609.pdf

- Nikolaichuk S., Sholomytskyi Y. (2015). Using Macroeconomic Models for Monetary Policy in Ukraine. Visnyk of the National Bank of Ukraine, No. 233, pp. 54-64. https://doi.org/10.26531/vnbu2015.233.054

- Petryk O., Nikolaichuk S. (2007). Vyznachennia optymalnoho rivnia infliatsii dlia Ukrainy, Visnyk of the National Bank of Ukraine, No. 6, pp. 10-22.

- Roger S. (2010). Inflation Targeting Turns 20. Finance \& Development, Vol. 47, No. 1, IMF, Washington D.C.

- Schaechter A., Stone M., Zelmer M. (2000). Adopting Inflation Targeting: Practical Issues for Emerging Market Countries, Occasional Paper, No. 202, IMF.

- Woodford M. (2003). Interest and Prices: Foundations of a Theory of Monetary Policy. Princeton University Press, Princeton. 